Cornell Law Library

Scholarship@Cornell Law: A Digital Repository

Cornell Law Faculty Publications

Faculty Scholarship

$12-2012$

\title{
Plea Bargaining and the Right to the Effective Assistance of Counsel: Where the Rubber Hits the Road in Capital Cases
}

John H. Blume

Cornell Law School, jb94@cornell.edu

Follow this and additional works at: http://scholarship.law.cornell.edu/facpub

Part of the Criminal Law Commons, Criminal Procedure Commons, and the Ethics and Professional Responsibility Commons

\section{Recommended Citation}

Blume, John H., "Plea Bargaining and the Right to the Effective Assistance of Counsel: Where the Rubber Hits the Road in Capital Cases" (2012). Cornell Law Faculty Publications. Paper 736.

http://scholarship.law.cornell.edu/facpub/736

This Article is brought to you for free and open access by the Faculty Scholarship at Scholarship@Cornell Law: A Digital Repository. It has been accepted for inclusion in Cornell Law Faculty Publications by an authorized administrator of Scholarship@Cornell Law: A Digital Repository. For more information, please contact jmp8@cornell.edu. 


\section{Plea Bargaining and the Right to the Effective Assistance of Counsel: Where the Rubber Hits the Road in Capital}

\section{Cases}

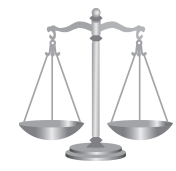

\section{JOHN H. BLUME}

Professor of Law Director of Clinical, Advocacy and Skills Programs Director, Cornell Death Penalty Project Cornell University School of Law
In Lafler v. Cooper ${ }^{1}$ and Missouri v. Frye, ${ }^{2}$ the Supreme Court recognized the obvious: the criminal justice system is "for the most part a system of pleas, not a system of trials." Very few criminal cases-less than three percent-go to trial. The rest are resolved through some form of a guilty plea. ${ }^{4}$ As scholars have noted, plea bargaining "is not some adjunct to the criminal justice system, it is the criminal justice system." Given the centrality of plea bargaining in the current criminal justice system, the Court recognized that "the negotiation of a plea bargain, rather than the unfolding of a trial, is almost always the critical point for a defendant." 6 Because of this "new normal," the Court concluded that a criminal defendant's trial counsel has "responsibilities in the plea bargain process . . that must be met to render the adequate assistance of counsel that the Sixth Amendment requires in the criminal process at critical stages."7

In Frye, the Court held that defense counsel have "the duty to communicate formal offers from the prosecution to accept a plea on terms and conditions that may be favorable to the accused." 8 It then concluded that that counsel's failure to do so was deficient performance under its wellestablished Strickland standard for adjudicating ineffective assistance of counsel claims, ${ }^{9}$ and remanded to the state court to determine whether the failure to communicate the offer was prejudicial, that is, whether there was a "reasonable probability that the end result of the criminal process would have been more favorable by reason of a plea offer to a lesser charge or a sentence of less prison time." ${ }^{\text {IO }}$ In Lafler, decided the same day as Frye, trial counsel advised the client to turn down a plea bargain based on an erroneous understanding of the law. At trial, the defendant was convicted and given a sentence three and one half times greater than he would have received under the plea. Therefore, it was conceded that counsel's performance was deficient. ${ }^{\text {II }}$ However, the Court rejected the state's argument that Cooper could not show prejudice because he was found guilty by a jury after a fair trial. It did so reasoning that "the question is not the fairness or reliability of the trial but the fairness and regularity of the processes that preceded it, which caused the defendant to lose benefits he would have received in the ordinary course but for counsel's ineffective assistance."12 The Court then held that ineffective assistance under Strickland had been satisfied and remanded to order for the state to re-offer the pretrial plea bargain.

Justice Scalia noted in dissent that the Court has opened "a whole new field of constitutionalized criminal procedure: plea bargaining law." ${ }^{\text {I3 }}$ And, at least to that extent, Justice Scalia is clearly correct. In the years to come, courts will inevitably be required to resolve a number of issues related to trial counsel's Sixth Amendment responsibilities to their clients during plea bargaining. In this short essay, I will discuss one issue of considerable importance to the criminal justice system, and one that has received little attention by courts or scholars: What are trial counsel's responsibilities when the prosecution offers a plea to life (or less) in cases where a defendant is facing the death penalty?

Like other criminal offenses, most death-eligible murder cases are resolved through guilty pleas. Some readers will be surprised to learn, however, that a very substantial percentage of the current population of death row-some estimate the number to be as high as seventy percent of the inmates ${ }^{\mathrm{I}}$ — refused to accept a plea bargain that would have spared their lives. ${ }^{15}$ After rejecting the prosecution's offer, most of these defendants went to trial, were found guilty at the guilt-or-innocence phase of the proceedings, and then were sentenced to death following a penalty hearing. Some had their convictions or sentences reversed at some point during the capital appeals process, but some were executed. In many of these cases, however, reasonably effective defense counsel would have persuaded the client to accept the plea.

I do not mean to suggest that it is per se unreasonable to fail to persuade a client to accept a plea bargain that will spare his or her life. The DNA exoneration cases, for example, have established that some capital defendants who refused to plead guilty and who were then convicted and sentenced to death were, in fact, innocent. ${ }^{16}$ However, in many of the death penalty cases in which defendants rejected life offers, there was no, or virtually no, chance that the defendant would be acquitted. ${ }^{17}$ Furthermore, given the nature of the offense, the defendant's prior record, and other aggravating evidence, it was certainly possible, if not probable, that the jury would sentence the defendant to death. Thus the "deal" that the prosecution was offering-

Federal Sentencing Reporter, Vol. 25, No. 2, pp. 36-39, ISSN 1053-9867, electronic ISSN 1533-8363. (C) 2012 Vera Institute of Justice. All rights reserved. Please direct requests for permission to photocopy or reproduce article content through the University of California Press's Rights and Permissions website, http://www.ucpressjournals.com/reprintInfo.asp. DOI: I0.I525/fsr.20I2.25.2.36. 
a guilty plea in exchange for a life sentence-represented in many cases either the most likely trial outcome or, from the defendant's perspective, the best possible trial outcome. ${ }^{\text {I8 }}$

If that is true, why don't many capital defendants accept a plea offer when it is in their best interest to do so? Interviews with experienced capital defense lawyers indicate several recurring reasons why capital clients reject favorable plea bargains: (I) the defendant does not trust his court-appointed counsel; (2) the defendant has (often significantly) underestimated the strength of the prosecution's case and/or likelihood of conviction at trial; (3) the defendant is too ashamed to admit his or her guilt to family and friends; and (4) the client's decision making is impaired by intellectual deficits, mental illness, and/or the stress of a pending capital trial. In some, if not many, cases, it is a combination of these reasons. But the same conversations with skilled capital trial lawyers also establishes that many, if not most, clients facing the ultimate punishment, can be persuaded to accept a plea offer when it is in their best interest to do so. Persuasion can often be a time-consuming and labor-intensive process, and it may require the defense team to enlist the assistance of others (e.g., the client's relatives, mental health professionals, inmates who accepted similar plea bargains), but reasonably competent counsel can in most cases convince a client that the substantial downside risks weigh against "rolling the dice" at trial. ${ }^{\text {I9 }}$ And it is certainly never reasonable for trial counsel for a capitally charged client to accept the client's initial rejection of a plea offer as ending the discussion. ${ }^{20}$

Given the number of cases in which people who rejected plea offers were sentenced to death, there have been remarkably few claims that trial counsel provided ineffective assistance for failing to persuade their client to accept the offered plea. ${ }^{2 \mathrm{I}}$ Regardless of the reasons for the dearth of litigation challenging counsel's lack of success in convincing a client to accept a favorable offer pre-Lafler and Frye $^{22}$ that will almost certainly change in the future, given the Supreme Court's recognition in those decisions that the negotiation of a favorable plea bargain is the "critical point" for most defendants and that defense counsel have

"responsibilities in the plea bargain process ... that must be met to render the adequate assistance of counsel that the Sixth Amendment requires." 23

The early evidence also suggests this is an area courts will be forced to confront. Since the Court's decision in Lafler and Frye, there have been four reported decisions in which death-sentenced inmates alleged ineffective assistance of counsel arising from trial counsel's failure to persuade them to accept a favorable plea bargain in a capital case. Three of the four decisions either assume without deciding or explicitly acknowledge that trial counsel in a capital case have a Sixth Amendment obligation to attempt to persuade their client to accept a plea bargain which would spare their lives. ${ }^{24}$ In State v. Fry, the Ohio Supreme Court assumed without deciding that counsel's performance was deficient for failing to enlist the defendant's family members to assist in convincing the defendant to accept a plea to life. ${ }^{25}$ And in Overstreet $v$. Wilson, a panel of the Seventh Circuit assumed, again without deciding, that the Supreme Court's recent decisions require counsel in a capital case not only to convey the offer, but to do so effectively. ${ }^{26}$ In both cases, the courts rejected the claim because the defendants failed to show prejudice.

The most detailed post-Frye and Lafler discussion of this emerging issue is found in Johnson v. United States, a collateral challenge to a federal death sentence. ${ }^{27}$ The petitioner in Johnson raised, among other claims, several challenges to counsel's performance in failing to persuade her to plead guilty in exchange for the government withdrawing the death penalty as a sentencing option. One claim centered around the fact that counsel spent little time explaining to Ms. Johnson the strength of the government's case against her; rather, the only team member who spent any substantial amount of time with the client was a paralegal, who blindly accepted Ms. Johnson's protestations of innocence. Thus, the defense team failed to speak with a unified voice, and they failed to enlist assistance from Johnson's family and friends to persuade her to accept the plea bargain. The District Court was clearly bothered by counsel's inactivity:

I find it very troubling that trial counsel were unable to present Johnson with a unified message that her only realistic course was to accept a plea agreement to life imprisonment; that they did not spend more time with Johnson, and sooner, discussing plea options; that they did not do more, and sooner, to marshal and confront Johnson with evidence suggesting that a plea to a life sentence was the only realistic option; and that they did not do more, and sooner, to enlist the aid of family members and others to convince her to plead guilty to the charges in order to escape the death penalty. ${ }^{28}$

However, the court was not persuaded that counsel's performance was outside the wide range of competent assistance.

Nevertheless, the District Court did find objectively unreasonable counsel's continued attempts to persuade the government to accept a term of years (as opposed to a life sentence) after Ms. Johnson's codefendant was sentenced to death. ${ }^{29}$ However, the court ultimately concluded that trial counsel's deficient performance was not prejudicial given Johnson's pretrial protestations of innocence and the corresponding lack of objective evidence that Johnson would have accepted such a plea offer. ${ }^{30}$

Despite the fact that Johnson's guilty plea claims failed ${ }^{3 \mathrm{I}}$ (as did the claims in the other cases discussed above), there are several reasons that counsel who represent deathsentenced inmates should be at least (modestly) encouraged by the decision as a potential harbinger of better things to come. First, Johnson is the first decision in the death penalty context that found trial counsel's performance to be deficient during the plea bargaining phase of 
a capital trial representation. In doing so, the court relied heavily upon the Supreme Court's recent decisions in Lafler and Frye. ${ }^{32}$ Second, given Lafler and Frye's clear statement that in the current world of pleas not trials, counsel have "responsibilities in the plea bargain process . . . that must be met to render the adequate assistance of counsel that the Sixth Amendment requires," and given the widely recognized norm in the capital defense bar that reasonably competent trial counsel can frequently persuade even the most reluctant capitally charged client to accept a favorable plea offer, it would seem to be only a matter of time before a judge is faced with a set of facts that warrant a finding of ineffective assistance of counsel.

\section{Notes}

1 Lafler v. Cooper, 132 S. Ct. 1376 (2012)

2 Missouri v. Frye, 132 S. Ct. 1399 (2012).

3 Lafler, 132 S. Ct. at 1376.

4 By "some form of guilty plea," I am referring to both negotiated pleas as well as "straight up" pleas where the client pleads guilty hoping for a more lenient sentence than would otherwise be obtained, and also to nolo contendere pleas and Alford pleas (one in which the client pleads guilty but expressly asserts her innocence).

5 Robert E. Scott \& William J. Stuntz, Plea Bargaining as Contract, 101 Yale L. J. 1909, 1912 (1992).

6 Frye, 132 S. Ct. at 1407 . Despite the many critiques of plea bargaining in the academic literature, the Court had no such reservations about the practice. Justice Kennedy stated: "To note the prevalence of plea bargaining is not to criticize it. The potential to conserve valuable judicial resources and for defendants to admit their crimes and receive more favorable terms at sentencing means that a plea agreement can benefit both parties." Id. Justice Scalia responded in dissent: "we have plea bargaining a-plenty but until today it has been regarded as a necessary evil. ... Today, however, the Supreme Court of the United States elevates plea bargaining from a necessary evil to a constitutional entitlement." Lafler, 132 S. Ct. at 1397.

7 Frye, 132 S. Ct. at 1407.

$8 \quad$ Id

9 Strickland v. Washington, 466 U.S. 668 (1984). Strickland established a two-prong test for assessing whether a criminal defendant was provided with the effective assistance of coun. sel. Prong one, often referred to as the deficient performance prong, asks whether counsel's performance was objectively reasonable under all the circumstances (or whether it was outside the wide range of competent assistance). Prong two, commonly referred to as the prejudice prong, asks whether there is a reasonable probability that, but for counsel's deficient performance, the outcome would have been different.

10 Frye, 132 S. Ct. at 1409.

11 Lafler, 132 S. Ct. at 1391.

12 Id. at 1387

13 Frye, 132 S. Ct. at 1413 (Scalia, J., dissenting).

14 Welsh S. White, Effective Assistance of Counsel in Capital Case: The Evolving Standard of Care, 1993 U. III. L. Rev. 323, 371 (1993).

15 I leave for another day the issue of whether reasonably effective defense counsel could have persuaded the prosecution to offer a life sentence in exchange for a guilty plea in cases where there was no life offer. However, as recent events have demonstrated, excellent lawyers can negotiate a life sentence even in cases that appear to be "unwinnable." See, e.g., Richard A. Serrano, Jared Loughner Pleads Guilty to Killing 6 in Tucson Shooting, L.A. Times, Aug. 7, 2012, available at http://www.latimes.com/ news/nation/nationnow/la-na-nn-jared-loughner-plead-guilty20120807,0,1931406.story (discussing Jared Loughner's guilty plea to life without parole for the murder of, inter alia, a federal judge and a young child, and for intending to kill Congresswoman Gabrielle Giffords).

16 In other cases, defendants facing the ultimate punishment pled guilty to crimes they did not commit in order to avoid the pos. sibility of being sentenced to death. See John H. Blume \& Rebecca Helm, The Unexonerated: Factually Innocent Defendants Who Plead Guilty, available at http://papers.ssrn.com/ sol3/papers.cfm?abstract_id=2103787.

17 The prospects of acquittal are further diminished by the fact that juries in capital cases are "death qualified," i.e., people whose views on capital punishment would impair their ability to follow the law are not eligible to serve on a jury where the death penalty is a sentencing option. Wainwright v. Witt, 469 U.S. 412 (1985). A well-established body of social science research has demonstrated that such juries are more "conviction prone" than non-death qualified juries. See, e.g., William Thompson, Claudia Cowen, Phoebe Ellsworth, \& Joan Harrington, Death Penalty Attitudes and Conviction Proneness: The Translation of Attitudes into Verdicts, 8 Law \& Hum. Behavior 95 (1984).

18 For example, Ted Bundy, the infamous serial killer, was offered, and initially accepted, a plea bargain that would have avoided the death penalty. He refused to go through with the "deal," and it was withdrawn. He was then tried, convicted, sentenced to death, and ultimately executed.

19 The client's resistance is often symptomatic of larger problems in the attorney-client relationship, the most common of which is that trial counsel has failed to spend sufficient time with the client and/or sufficient time investigating the case to obtain the client's trust. The American Bar Association's Guidelines for the Appointment and Performance of Defense Counsel in Death Penalty Cases, which have been relied upon by the Supreme Court in numerous cases as shedding light on the appropriate stan. dard of care, see, e.g., Rompilla v. Beard, 545 U.S. 374, 387 (2005), state that "[c]ounsel at all stages of the case should make every appropriate effort to establish a relationship of trust with the client, and should maintain contact with the client," Guideline 10.5.A, and that "[C]ounsel at all stages should engage in a continuing interactive dialogue with client con cerning ...: 1 . the factual investigation ...; 3 . the development of a defense theory; ... 5. potential agreed-upon dispositions of the case ... ," Guideline 10.5.C. See also Russell Stetler, Commentary on Counsel's Duty to Seek and Negotiate a Disposition in Capital Cases, 31 Hofstra L. Rev. 157, 1157 (2003); Rick Kammen \& Lee Norton, Plea Agreements: Working with Capital Defendants, the Advocate, March 2000, available at http:// www.e-archives.ky.gov/pubs/Public_Adv/mar00/plea.html.

20 See ABA Guideline 10.9.1, "The duty to seek an agreed-upon disposition," which states: "(A) Counsel at every stage of the case have an obligation to take all steps that may be appro. priate in the exercise of professional judgment ... to achieve an agreed-upon disposition. ... (E) . . . a client's . . opposition should not prevent counsel from engaging in an ongoing effort to persuade the client to accept an offer of resolution that is in the client's best interest."

21 In fact, prior to Frye and Lafler, I found only one decision involving such a claim in a capital case. In Jones v. Murray, 947 F. 2d 1106 (4th Cir. 1991), the Fourth Circuit rejected a death sentenced inmate's claim that trial counsel's failure to persuade the defendant to accept the prosecution's two. consecutive-life-term offer was unreasonable. Counsel had indicated that he explained the offer to his client, but acknowledged that he did not attempt to convince his client to accept it, even though he believed there was more than a seventy percent chance of conviction and a fifty percent chance of a death sentence. The court held that given the 
client's stated reason for rejecting the offer, i.e., that he was innocent, "to refrain from a vigorous attempt to change his client's mind" was not unreasonable. Id. at 1111 . There are a small handful of capital cases involving claims challenging counsel's advice to reject a plea offer, but those are not the focus of this article. I focus here on cases where trial counsel was either "neutral" or advised the client that he should accept the plea offer.

22 The dearth of claims is probably explained by a combination of factors including: uncertainty prior to Lafler and Frye about whether plea bargaining was a "critical stage" of the proceed. ings to which the Sixth Amendment right to counsel (and thus the right to the effective assistance of counsel) applied; a widely held belief that the client's autonomy interests counsel against attempting to "coerce" the client into accepting a plea he is resistant to accepting; and difficulties-but not insurmountable ones-inherent in attempting to prove a "what if" coun. terfactual scenario.

23 Frye, 132 S. Ct. at 1407.

24 The fourth decision was decided in the federal habeas corpus context. The United States Court of Appeals for the Eleventh
Circuit held that a state court determination that trial counsel has no duty to convince a defendant to take a plea was not objectively unreasonable and thus the petitioner was not enti. tled to relief in light of 28 U.S.C. §2254(d). Gissendaner v. Seabolt, 2012 WL 2062398 (N.D. Ga. 2012).

25 State v. Fry, 2012 WL 2128027 (Ohio 2012).

26 Overstreet v. Wilson, 2012 WL 2829296 (7th Cir. 2012).

27 Johnson v. United States, 2012 WL 1836282 (N.D. Iowa 2012).

28 Id. at 84.

29 Id. ("The performance in plea negotiations that I do find deficient was their continued push for an agreement to a sentence for a term of years, once a plea to a term of years became both wholly unrealistic and wholly unreasonable as a bargaining position.").

30 Id. at $87,88$.

31 Johnson did prevail, however, on other grounds, i.e., trial counsel's presentation of mental health evidence was both deficient and prejudicial. Because the government cannot appeal a grant of postconviction relief pursuant to 28 U.S.C. $\S 2255$, Johnson will receive a new sentencing trial.

32 Id. at 80. 